\title{
Identifikasi Sampah Berdasarkan Tekstur dengan Metode GLCM dan GLRLM Menggunakan Improved KNN
}

\author{
Kristian Telaumbanua ${ }^{1}$, Sudarto $^{2}$, Fitri Butar-Butar ${ }^{3}$, Putri Shania Bilqis ${ }^{4}$ \\ 1,2,3,4 Program Studi Teknik Informatika, STMIK Mikroskil, Medan, Indonesia \\ e-mail: ${ }^{1}$ kristian@mikroskil.ac.id, ${ }^{2}$ sudarto@ mikroskil.ac.id, ${ }^{3}$ fitributar.butar12@gmail.com, \\ ${ }^{4}$ putrishaniabilqis@gmail.com,
}

\begin{abstract}
Abstrak-Sampah dapat menimbulkan kerugian seperti menyebabkan banjir hingga menjadi ancaman meningkatnya berbagai penyakit. Sampah organik merupakan sampah yang bisa dengan mudah terurai secara alami dan sampah anorganik yang membutuhkan waktu sangat lama untuk bisa terurai secara alami. Untuk melakukan ekstraksi fitur tekstur ciri khas jenis sampah anorganik seperti tekstur kaca, metal, kertas, plastic dan kardus dengan akurasi yang baik perlu dilakukan dengan menerapkan metode Gray Level Co-occurrence Matrix (GLCM) untuk menentukan co-occurrence yang menunjukkan hubungan antara level keabuan dalam citra tekstur dan Gray Level Run Length Matrix (GLRLM) yang mampu membedakan citra halus dan citra kasar. Kemudian untuk penentuan jenis sampah pada citra akan menggunakan metode klasifikasi Improved K-Nearest Neighbor. Hasil pengujian dengan 50 citra uji dari 5 jenis material sampah yang berbeda yaitu sampah berbahan karton atau kardus, kaca, metal, kertas, dan plastik, menghasilkan nilai rata-rata accuracy tertinggi yaitu sebesar 90,4\% yang diperoleh pada penggunaan metode ekstraksi GLRLM dengan besar sudut ekstraksi $135^{\circ}$. Sedangkan saat menggunakan kedua metode ekstraksi, yaitu dengan menggabungkan nilai-nilai ciri dari metode GLCM dan GLRLM nilai rata-rata accuracy tertinggi yang diperoleh sebesar $88 \%$ dengan besar sudut ekstraksi $0^{\circ}$.
\end{abstract}

Kata kunci: sampah organik, sampah anorganik, gray level co-occurrence matrix, gray level run length matrix, improved knearest neighbor.

\begin{abstract}
Garbage can cause losses such as causing flooding to become a threat to increasing various diseases. Garbage organic waste, which is waste that can easily decompose naturally and inorganic waste which takes a very long time to decompose naturally. To extract texture features characteristic of inorganic waste types such as glass, metal, paper, plastic and cardboard with good accuracy, it is necessary to apply the Gray Level Co-occurrence Matrix (GLCM) method to determine co-occurrence which shows the relationship between gray level in texture images and Gray Level Run Length Matrix (GLRLM) which is able to distinguish between fine and coarse images. Then to determine the type of garbage in the image will use the Improved KNearest Neighbor classification method. The results of the test by using 50 images as data testing from 5 different material of garbage which is cardboard, glass, metal, paper, and plastic type of garbage have the highest mean of accuracy $90,4 \%$ by using the GLRLM method with $135^{\circ}$ angle of extraction. Meanwhile the accuracy when combining the extraction methods, which is adding up the value of GLCM and GLRLM, have the highest mean of accuracy $88 \%$ with $0^{\circ}$ angle of extraction.
\end{abstract}

Keywords: organic garbage, inorganic garbage, gray level co-occurrence matrix, gray level run length matrix, improved knearest neighbor.

\section{PENDAHULUAN}

Sampah anorganik yang tertimbun di tanah dapat menyebabkan pencemaran tanah karena sampah anorganik tergolong zat yang sulit terurai dan sampah itu akan tertimbun dalam tanah dalam waktu lama, ini menyebabkan rusaknya lapisan tanah. Sampah anorganik misalnya berupa karton, kaca, logam, plastik, dan kertas [1]. Salah satu pemanfaatan sampah anorganik adalah dengan cara proses daur ulang (recycle). Sampah yang sudah dikelompokkan berdasarkan jenisnya akan mempermudah proses daur ulang.

Saat ini untuk klasifikasi atau pengelompokan jenis sampah dilakukan dengan memerlukan tenaga manusia secara manual, padahal untuk dapat mengklasifikasikan jenis sampah bisa dilakukan secara otomatis dengan sistem. Yaitu sebuah aplikasi yang dapat mengidentifikasi jenis sampah berdasarkan gambar masukan. Dengan menganalisis ciri atau fitur gambar masukan seperti fitur warna, bentuk, dan tekstur. Beragam teknik pengolahan citra digital telah dikembangkan untuk permasalahan identifikasi dengan fitur tekstur seperti ini, diantaranya dengan Gray Level Co-occurence Matrix (GLCM) dan Gray Level Run Length Matrix (GLRLM) [2]. GLCM untuk melihat jumlah intensitas piksel yang berpasangan dan dibentuk menjadi matkriks co-occurrence yang menunjukkan hubungan antara level keabuan dalam citra tekstur [3]. Metode GLRLM mampu membedakan citra halus dan citra kasar, dimana citra yang memiliki tekstur halus akan memiliki sedikit piksel tetangga yang intensitasnya sama sedangkan yang memiliki tekstur kasar akan memiliki banyak piksel tetangga yang intensitasnya sama [4].

Banyak penelitian untuk identifikasi objek yang telah dilakukan sebelumnya, seperti penelitian yang dilakukan oleh Diny Hafizha [4] tentang identifikasi biometrik pola pada enamel gigi menggunakan metode Gray Level Run Length Matrix (GLRLM), yang mana nilai akurasinya mencapai $84 \%$ dalam waktu komputasi rata-rata 0,7707 detik, menggunakan data latih yang terdiri dari 100 citra dan data uji sebanyak 200 citra dari 10 sample gigi. Penelitian oleh Purwandari untuk mengidentifikasikan jenis bambu berdasarkan tekstur daun yang 
menggunakan metode Gray Level Co-occurrence Matrix (GLCM) dan Gray Level Run Length Matrix (GLRLM) dengan akurasi yang tinggi yaitu $100 \%$ untuk citra uji yang diambil langsung menggunakan smarthphone dan $81,25 \%$ untuk citra uji yang diunduh dari internet [3]. Pada penelitian tersebut, keberhasilan pengujian pada sistem dengan menggunakan citra uji yang diambil dari internet mengalami 3 kegagalan dikarenakan nilai kekerasan dan kehalusan dari citra internet yang mempengaruhi nilai ekstraksi fitur GLRLM, dan besarnya nilai kontras dari citra yang mempengaruhi nilai ekstraksi fitur GLCM. Kombinasi fitur GLCM dan GLRLM juga meminimalkan kesalahan dalam identifikasi citra internet sehingga mampu mendapatkan akurasi yang memadai, yaitu sebesar $81,25 \%$ [3].

Pada penelitian klasifikasi citra makanan tunggal menggunakan Improved K-Nearest Neighbor (KNN) sebagai metode klasifikasi yang dipadukan dengan metode Local Binary Patterns, dan Hue Saturation Value yang dilakukan oleh Sarah Najla Adha, bahwa metode klasifikasi Improved K-Nearest Neighbor menghasilkan rata-rata akurasi lebih tinggi daripada metode K-Nearest Neighbor [5].

Dalam penelitian ini, dilakukan pengidentifikasi jenis sampah berdasarkan ekstraksi fitur tekstur. Dengan demikian, maka diperlukan suatu model untuk mengidentifikasi jenis sampah dengan menggunakan metode Grey Level Co-Occurrence Matrix (GLCM) dan Gray Level Run Length Matrix (GLRLM), dan metode klasifikasi Improved K-Nearest Neighbor serta pengukuran kinerja algoritma klasifikasi Improved K-Nearest Neighbor dari sudut pandang akurasi, presisi dan sensitivitas (recall).

\section{METODE PENELITIAN}

\subsection{Pengumpulan Data}

Pada penelitian ini menggunakan data citra latih berjumlah 150 gambar yang didapatkan dari situs kaggle, dengan nama akun pengunggah: cchangcs. Citra latih terdiri dari lima kategori dengan jumlah yang berbeda pada tiap kategorinya yaitu 25 gambar sampah berbahan kaca (glass), 45 gambar sampah berbahan metal, 20 gambar sampah berbahan kertas (paper), 30 gambar sampah berbahan plastic (plastic), dan 30 gambar sampah kardus (cardboard).

\subsection{Model yang diusulkan}

Pada Model yang diusulkan untuk mengidentifikasi sampah yaitu dengan mengekstraksi fitur tekstur menggunakan metode Gray Level Run Length Matrix (GLRLM) dan Grey Level Co-Occurrence Matrix (GLCM) serta penerapan metode klasifikasi Improved K-Nearest Neighbor. Kerangka kerja yang diusulkan dalam penelitian ini ditunjukkan pada gambar 1 .

Pada model yang diusulkan, identifikasi jenis sampah berdasarkan tekstur dengan metode Gray Level Run Lenght Matrix (GLRLM) dan Gray Level Co-Occurence Matrix (GLCM) menggunakan Improved K-Nearest Neighbor, dimulai dengan pemilihan gambar yang kemudian akan dijadikan citra uji. Selanjutnya, akan dilakukan pemilihan metode ekstraksi yang digunakan yaitu dengan memilih metode GLCM atau metode GLRLM, ataupun keduanya untuk dijadikan metode ekstraksi. Setelah itu, proses ekstraksi akan dilakukan pertama kali pada folder dataset, hasil ekstraksi dari folder dataset akan disimpan dengan format (.txt) yang akan digunakan untuk proses klasifikasi selanjutnya. Setelah selesai dengan dataset, ekstraksi akan dilakukan pada citra uji yang sebelumnya telah dipilih, kemudian hasilnya akan diklasifikasi menggunakan Improved K-Nearest Neighbor (KNN).

\subsection{Klasifikasi Citra dengan Improved $\mathrm{KNN}$}

Improved K-Nearest Neighbor merupakan pengembangan dari metode K-Nearest Neighbor (K-NN), yang mana perbedaannya terdapat pada pembobotan nilai $k$ [5]. Pada Improved K-NN dilakukan perhitungan bobot pada tiap data latih berdasarkan data uji [6] dan data latih lainnya, serta kelas dari data uji ditentukan oleh bobot data latih yang terbesar. 


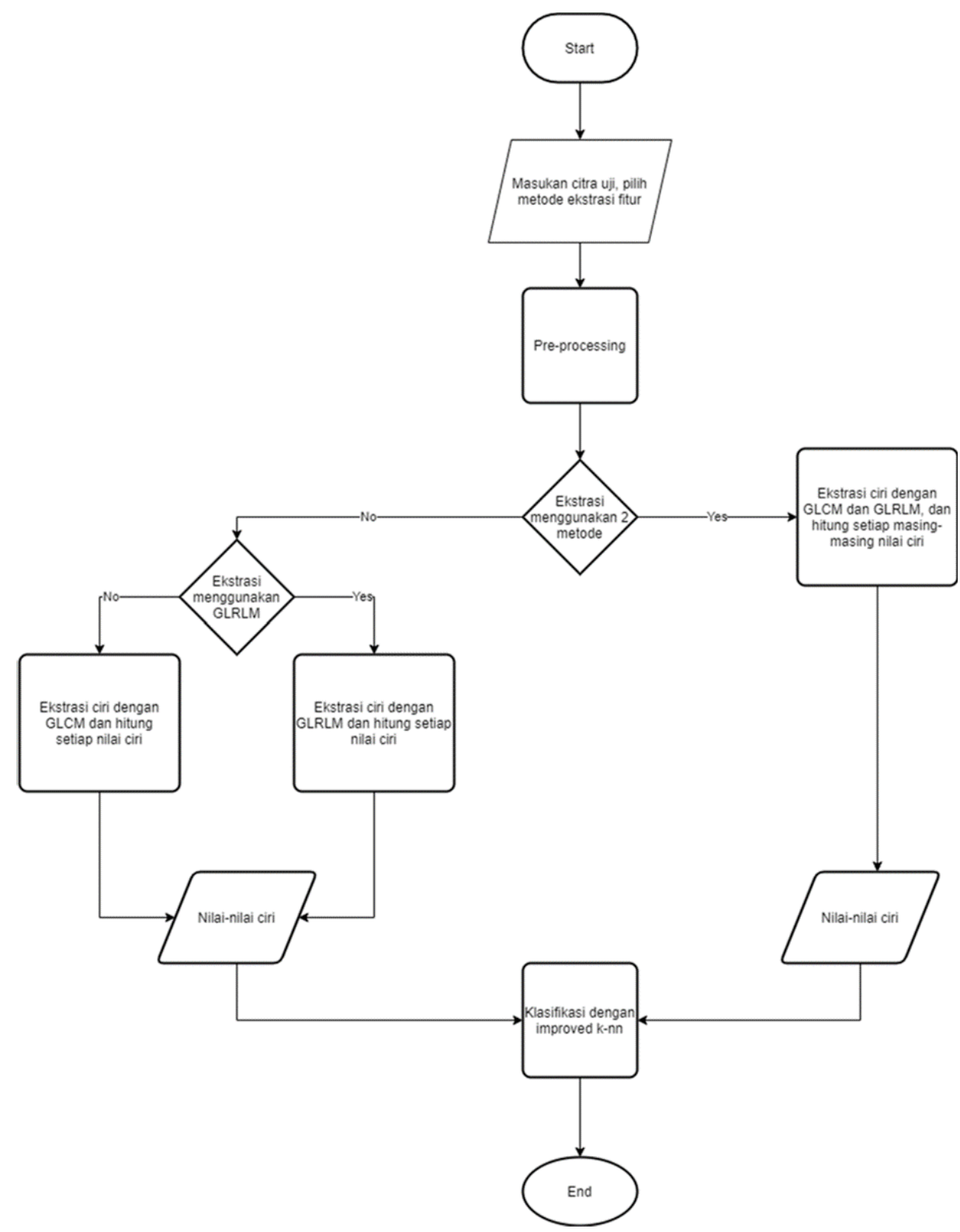

Gambar 1. Kerangka Kerja Model yang diusulkan

Langkah-langkah dari Improved K-nearest Neighbor sebagai berikut [6] :

1. Cari sejumlah $k$ nearest neighbor pada data latih, dengan menghitung jarak antar data uji dengan dengan data latih menggunakan rumus Euclidean:

$D(a, b)=\sum_{i=1}^{A} \sqrt{\left(a_{i}-b_{i}\right)}$

Keterangan:

$A$ : jumlah fitur

$a_{i}$ : fitur data latih ke- $i$

$b_{i}$ : fitur data uji ke- $i$

2. Kemudian berdasarkan nearest neighbor yang sudah didapatkan, prediksi kelas dari data uji dengan rumus:

$y^{\prime}=\operatorname{argmax}_{y} \sum_{\left(x i^{N N}, y i\right.}{ }^{N N} w^{\prime} i \times \delta\left(y=y i^{N N}\right)$

Keterangan:

$x i^{N N}:$ data uji 


$$
\begin{aligned}
& y i^{N N}: \text { nearest neighbor ke- } i \\
& w^{\prime} i \quad: \text { bobot dari nearest neighbor ke- } i
\end{aligned}
$$

$$
\text { Dimana } \delta\left(y=y i^{N N}\right)=\left\{\begin{array}{l}
1, y=y i^{N N} \\
0, y \neq y i^{N N}
\end{array}\right.
$$

Keterangan:

$$
y \quad: \text { nearest neighbor ke- } i
$$

$y i^{N N}$ : data latih ke-i

\subsection{Confusion Matrix}

Pengukuran kinerja algoritma pengklasifikasi dilakukan dengan menggunakan confusion matrix. Dimana confunsion matrix diperoleh dari proses validasi. Mengevaluasi kinerja algoritma klasifikasi umumnya menggunakan hasil keseluruhan pada pengujian dataset [7]. Sebuah matrix dari prediksi yang akan dibandingkan dengan kelas yang asli dari masukan (input) atau dengan kata lain berisi informasi nilai aktual dan prediksi pada klasifikasi [8]. Confusion matrix dapat membantu menunjukkan rincian kinerja pengklasifikasi dengan memberikan informasi jumlah fitur suatu kelas yang diklasifikasikan dengan tepat dan tidak tepat [9].

Tabel 1. Confusion Matrix

\begin{tabular}{|c|c|c|}
\hline Kategori $\mathbf{x}$ & \multicolumn{2}{|c|}{ Predicted } \\
\hline \multirow{3}{*}{ Actual } & True positive & False positive \\
\cline { 2 - 3 } & $\begin{array}{c}\text { False } \\
\text { negative }\end{array}$ & True negative \\
\hline
\end{tabular}

Keterangan:

- True Positive (TP), jumlah dokumen dari kelas 1 yang benar dan diklasifikasikan sebagai kelas 1.

- True Negative (TN), jumlah dokumen dari kelas 0 yang benar diklasifikasikan sebagai kelas 0 .

- False Positive (FP), jumlah dokumen dari kelas 0 yang salah diklasifikasikan sebagai kelas.

- False Negative (FN), jumlah dokumen dari kelas 1 yang salah diklasifikasikan sebagai kelas 0.

Evaluasi dan validasi hasil dihitung menggunakan rumus akurasi, precision, dan recall berikut ini [10]:

1. Akurasi $=\frac{T P+T N}{T P+T N+F P+F N}$

2. Precision $=\frac{T P}{T P+F P}$

3. Recall $=\frac{T P}{T P+F N}$

\section{HASIL DAN PEMBAHASAN}

\subsection{Hasil}

Penelitian ini menghasilkan keluaran yang dapat dianalisis untuk menghasilkan informasi dan pengetahuan yang berguna melalui proses dan hasil eksperimen yang sudah dilakukan dengan menggunakan bahasa pemrograman C\#. Proses pengujian dilakukan dengan 5 citra uji sampah berbahan kaca, sampah berbahan metal, sampah berbahan kertas, sampah berbahan plastik, dan sampah kardus. Citra uji harus merupakan salah satu dari 5 kategori jenis sampah yang tersedia yaitu sampah berbahan kaca, sampah berbahan metal, sampah berbahan kertas, sampah berbahan plastik, dan sampah kardus. Citra yang diproses berformat .jpg dengan ukuran 512 x 384 . Dalam pengujian, user dapat memilih untuk menggunakan metode GLCM untuk ekstraksi fitur atau menambahkannya dengan metode GLRLM. Setelah proses klasifikasi selesai dan didapatkan jenis dari sampah pada citra uji, hasil nilai dari ekstraksi berupa Angular Second Moment (ASM), Kontras, Inverse Different Moment (IDM), dan Korelasi untuk metode GLCM. Sementara Short Run Emphasis (SRE), Long Runs Emphasis (LRE), Grey Level Uniformity (GLU), Run Length Uniformity (RLU), dan Run Percentage (RP) untuk metode GLRLM.

Pada metode GLRLM dan metode GLCM menggunakan sudut $0^{\circ}, 45^{\circ}, 90^{\circ}, 135^{\circ}$ dan jarak antar piksel sebesar 1 [11]. Dimana untuk sudut $0^{\circ}$, ketetanggaan piksel dihitung dengan jarak satu piksel ke kanan. Untuk sudut $45^{\circ}$, ketetanggaan piksel dihitung dengan jarak satu piksel ke kanan atas. Untuk sudut $90^{\circ}$, ketetanggaan 
piksel dihitung dengan jarak satu piksel ke atas. Untuk sudut $135^{\circ}$ ketetanggaan piksel dihitung dengan jarak satu piksel ke kiri atas.

Tabel 2. Confusion Matrix dengan metode GLCM Sudut $0^{0}$

\begin{tabular}{|c|c|c|c|c|}
\hline No & Kategori & Accuracy & Precision & Recall \\
\hline 1 & Karton & $82 \%$ & $54 \%$ & $60 \%$ \\
\hline 2 & Kaca & $82 \%$ & $55 \%$ & $50 \%$ \\
\hline 3 & Logam & $88 \%$ & $66 \%$ & $80 \%$ \\
\hline 4 & Kertas & $94 \%$ & $88 \%$ & $80 \%$ \\
\hline 5 & Plastik & $90 \%$ & $77 \%$ & $70 \%$ \\
\hline \multicolumn{2}{|c|}{ Average } & $\mathbf{8 7 , 2 \%}$ & $\mathbf{6 8 \%}$ & $\mathbf{6 8 \%}$ \\
\hline
\end{tabular}

Tabel 3. Confusion Matrix dengan metode GLCM Sudut $45^{\circ}$

\begin{tabular}{|c|c|c|c|c|}
\hline No & Kategori & Accuracy & Precision & Recall \\
\hline 1 & Karton & $90 \%$ & $69 \%$ & $90 \%$ \\
\hline 2 & Kaca & $84 \%$ & $75 \%$ & $30 \%$ \\
\hline 3 & Logam & $84 \%$ & $60 \%$ & $60 \%$ \\
\hline 4 & Kertas & $96 \%$ & $90 \%$ & $90 \%$ \\
\hline 5 & Plastik & $82 \%$ & $53 \%$ & $70 \%$ \\
\hline & Average & $\mathbf{8 7 , 2 \%}$ & $\mathbf{6 9 , 4 \%}$ & $\mathbf{6 8 \%}$ \\
\hline
\end{tabular}

Tabel 4. Confusion Matrix dengan metode GLCM sudut $90^{\circ}$

\begin{tabular}{|c|c|c|c|c|}
\hline No & Kategori & Accuracy & Precision & Recall \\
\hline 1 & Karton & $74 \%$ & $33 \%$ & $30 \%$ \\
\hline 2 & Kaca & $84 \%$ & $58 \%$ & $70 \%$ \\
\hline 3 & Logam & $86 \%$ & $61 \%$ & $80 \%$ \\
\hline 4 & Kertas & $92 \%$ & $87,5 \%$ & $70 \%$ \\
\hline 5 & Plastik & $68 \%$ & $12,5 \%$ & $10 \%$ \\
\hline & Average & $\mathbf{8 0 , 8 \%}$ & $\mathbf{5 0 , 4 \%}$ & $\mathbf{5 2 \%}$ \\
\hline
\end{tabular}

Tabel 5. Confusion Matrix dengan metode GLCM sudut $135^{0}$

\begin{tabular}{|c|c|c|c|c|}
\hline No & Kategori & Accuracy & Precision & Recall \\
\hline 1 & Karton & $86 \%$ & $61 \%$ & $80 \%$ \\
\hline 2 & Kaca & $84 \%$ & $60 \%$ & $60 \%$ \\
\hline 3 & Logam & $86 \%$ & $71 \%$ & $50 \%$ \\
\hline 4 & Kertas & $92 \%$ & $75 \%$ & $90 \%$ \\
\hline 5 & Plastik & $92 \%$ & $87,5 \%$ & $70 \%$ \\
\hline \multicolumn{2}{|c|}{ Average } & $\mathbf{8 8 \%}$ & $\mathbf{7 0 , 9 \%}$ & $\mathbf{7 0 \%}$ \\
\hline
\end{tabular}

Tabel 2 hingga tabel 5 menunjukkan hasil eksperimen pertama yang dilakukan secara iteratif dengan metode GLCM menggunakan sudut $0^{\circ}, 45^{\circ}, 90^{\circ}, 135^{\circ}$ dan jarak antar piksel sebesar 1 dengan metode klasifikasi Improved K-nearest Neighbor. Nilai rata-rata akurasi, presisi dan sensitivitas (recall) pada sudut $0^{0}$ dan $45^{0}$ memiliki kecenderungan hasil yang sama. Namun terjadi peningkatan pada sudut $135^{\circ}$.

Pada eksperimen kedua dilakukan dengan menerapkan metode GLRLM dalam mengekstraksi fitur dan metode klasifikasi Improved K-nearest Neighbor. Hasil pengukuran dari ekstraksi fitur pada eksperimen kedua ditunjukkan pada tabel 6 hingga tabel 9.

Tabel 6. Confusion Matrix dengan metode GLRLM Sudut $0^{0}$

\begin{tabular}{|c|c|c|c|c|}
\hline No & Kategori & Accuracy & Precision & Recall \\
\hline 1 & Karton & $94 \%$ & $81 \%$ & $90 \%$ \\
\hline 2 & Kaca & $94 \%$ & $88 \%$ & $80 \%$ \\
\hline 3 & Logam & $84 \%$ & $58 \%$ & $70 \%$ \\
\hline
\end{tabular}




\begin{tabular}{|l|c|c|c|c|}
\hline 4 & Kertas & $94 \%$ & $81 \%$ & $90 \%$ \\
\hline 5 & Plastik & $82 \%$ & $57 \%$ & $40 \%$ \\
\hline \multicolumn{2}{|c|}{ Average } & $\mathbf{8 9 , 6 \%}$ & $\mathbf{7 3 \%}$ & $\mathbf{7 4 \%}$ \\
\hline
\end{tabular}

Tabel 7. Confusion Matrix dengan metode GLRLM Sudut $45^{\circ}$

\begin{tabular}{|c|c|c|c|c|}
\hline No & Kategori & Accuracy & Precision & Recall \\
\hline 1 & Karton & $98 \%$ & $90 \%$ & $100 \%$ \\
\hline 2 & Kaca & $90 \%$ & $77 \%$ & $70 \%$ \\
\hline 3 & Logam & $86 \%$ & $61 \%$ & $80 \%$ \\
\hline 4 & Kertas & $88 \%$ & $83 \%$ & $50 \%$ \\
\hline 5 & Plastik & $86 \%$ & $63 \%$ & $70 \%$ \\
\hline \multicolumn{2}{|c|}{ Average } & $\mathbf{8 9 , 6 \%}$ & $\mathbf{7 4 , 8 \%}$ & $\mathbf{7 4 \%}$ \\
\hline
\end{tabular}

Tabel 8. Confusion Matrix dengan metode GLRLM Sudut $90^{\circ}$

\begin{tabular}{|c|c|c|c|c|}
\hline No & Kategori & Accuracy & Precision & Recall \\
\hline 1 & Karton & $94 \%$ & $76 \%$ & $100 \%$ \\
\hline 2 & Kaca & $90 \%$ & $72 \%$ & $80 \%$ \\
\hline 3 & Logam & $74 \%$ & $33 \%$ & $30 \%$ \\
\hline 4 & Kertas & $92 \%$ & $87,5 \%$ & $70 \%$ \\
\hline 5 & Plastik & $78 \%$ & $44 \%$ & $40 \%$ \\
\hline \multicolumn{2}{r}{ Average } & $\mathbf{8 5 , 6 \%}$ & $\mathbf{6 2 , 5 \%}$ & $\mathbf{6 4 \%}$ \\
\hline
\end{tabular}

Tabel 9. Confusion Matrix dengan metode GLRLM Sudut $135^{\circ}$

\begin{tabular}{|c|c|c|c|c|}
\hline No & Kategori & Accuracy & Precision & Recall \\
\hline 1 & Karton & $96 \%$ & $83 \%$ & $100 \%$ \\
\hline 2 & Kaca & $88 \%$ & $70 \%$ & $70 \%$ \\
\hline 3 & Logam & $86 \%$ & $66 \%$ & $60 \%$ \\
\hline 4 & Kertas & $90 \%$ & $72 \%$ & $80 \%$ \\
\hline 5 & Plastik & $92 \%$ & $87,5 \%$ & $70 \%$ \\
\hline \multicolumn{2}{|c|}{ Average } & $\mathbf{9 0 , 4 \%}$ & $\mathbf{7 5 , 7 \%}$ & $\mathbf{7 6 \%}$ \\
\hline
\end{tabular}

Tabel 6 hingga tabel 9 menunjukkan dengan penerapan metode GLRLM dalam ekstraksi fitur pada klasifikasi Improved K-nearest Neighbor, akurasi, presisi dan sensitivitas (recall) untuk setiap besar sudut semakin lebih baik dari eksperimen sebelumnya. Saat pengujian dilakukan pada sudut $135^{\circ}$ rata-rata akurasi mencapai sebesar 90,4 $\%$. Pada eksperimen ketiga dengan metode ekstraksi GLCM dan GLRLM dilakukan dengan menggabungkan ciri ekstraksi dari kedua metode yaitu 4 ciri dari metode GLCM dan 5 ciri dari metode GLRLM, sehingga pada tahap klasifikasinya dengan metode Improved K-nearest Neighbor akan menggunakan total 9 nilai ciri yaitu : Angular Second Moment (ASM), Kontras, Inverse Different Moment (IDM), Korelasi, Short Run Emphasis (SRE), Long Run Emphasis (LRE), Gray Level Uniformity (GLU), Run Length Uniformity (RLU) dan Run Percentage (RP). Ekstraksi ciri dilakukan menggunakan 4 sudut yang berbeda yaitu sudut $0^{\circ}, 45^{\circ}, 90^{\circ}$ dan sudut $135^{\circ}$ dengan jarak antar piksel $(\mathrm{d})=1$. Hasil pengukuran dari penggabungan kedua metode pada eksperimen ketiga ditunjukkan pada tabel 10 hingga tabel 13 .

Tabel 10. Confusion Matrix dengan Penggabungan metode Sudut $0^{0}$

\begin{tabular}{|c|c|c|c|c|}
\hline No & Kategori & Accuracy & Precision & Recall \\
\hline 1 & Karton & $92 \%$ & $80 \%$ & $80 \%$ \\
\hline 2 & Kaca & $80 \%$ & $50 \%$ & $50 \%$ \\
\hline 3 & Logam & $88 \%$ & $75 \%$ & $60 \%$ \\
\hline 4 & Kertas & $96 \%$ & $83 \%$ & $100 \%$ \\
\hline 5 & Plastik & $84 \%$ & $60 \%$ & $60 \%$ \\
\hline \multicolumn{2}{|c|}{ Average } & $88 \%$ & $69,6 \%$ & $70 \%$ \\
\hline
\end{tabular}


Tabel 11. Confusion Matrix dengan Penggabungan metode Sudut $45^{0}$

\begin{tabular}{|c|c|c|c|c|}
\hline No & Kategori & Accuracy & Precision & Recall \\
\hline 1 & Karton & $70 \%$ & $33 \%$ & $50 \%$ \\
\hline 2 & Kaca & $80 \%$ & $50 \%$ & $40 \%$ \\
\hline 3 & Logam & $92 \%$ & $80 \%$ & $80 \%$ \\
\hline 4 & Kertas & $94 \%$ & $100 \%$ & $70 \%$ \\
\hline 5 & Plastik & $88 \%$ & $70 \%$ & $70 \%$ \\
\hline \multicolumn{2}{|c|}{ Average } & $\mathbf{8 4 , 8 \%}$ & $\mathbf{6 6 , 6 \%}$ & $\mathbf{6 2 \%}$ \\
\hline
\end{tabular}

Tabel 12. Confusion Matrix dengan Penggabungan metode Sudut $90^{\circ}$

\begin{tabular}{|c|c|c|c|c|}
\hline No & Kategori & Accuracy & Precision & Recall \\
\hline 1 & Karton & $76 \%$ & $40 \%$ & $40 \%$ \\
\hline 2 & Kaca & $78 \%$ & $45 \%$ & $50 \%$ \\
\hline 3 & Logam & $94 \%$ & $88 \%$ & $80 \%$ \\
\hline 4 & Kertas & $94 \%$ & $88 \%$ & $80 \%$ \\
\hline 5 & Plastik & $78 \%$ & $45 \%$ & $50 \%$ \\
\hline \multicolumn{2}{|c|}{ Average } & $\mathbf{8 4 \%}$ & $\mathbf{6 1 , 2 \%}$ & $\mathbf{6 0 \%}$ \\
\hline
\end{tabular}

Tabel 13. Confusion Matrix dengan Penggabungan metode Sudut $135^{0}$

\begin{tabular}{|c|c|c|c|c|}
\hline No & Kategori & Accuracy & Precision & Recall \\
\hline 1 & Karton & $84 \%$ & $58 \%$ & $70 \%$ \\
\hline 2 & Kaca & $84 \%$ & $62,5 \%$ & $50 \%$ \\
\hline 3 & Logam & $86 \%$ & $66 \%$ & $60 \%$ \\
\hline 4 & Kertas & $86 \%$ & $80 \%$ & $40 \%$ \\
\hline 5 & Plastik & $84 \%$ & $56 \%$ & $90 \%$ \\
\hline \multicolumn{2}{|c|}{ Average } & $\mathbf{8 4 , 8 \%}$ & $\mathbf{6 4 , 5 \%}$ & $\mathbf{6 2 \%}$ \\
\hline
\end{tabular}

Tabel 10 hingga tabel 13 menunjukkan rata-rata nilai akurasi, presisi dan sensitivitas (recall) tertinggi dengan menggabungkan kedua metode GLCM dan GLRLM pada klasifikasi Improved K-nearest Neighbor yaitu sebesar $88 \%$ pada sudut $0^{0}$.

\subsection{Pembahasan}

Dari hasil pengukuran beberapa eksperimen yang dilakukan dapat dikatakan bahwa peningkatan kinerja akurasi, presisi dan sensitivitas (recall) pada klasifikasi Improved K-nearest Neighbor, dipengaruhi dengan adanya penerapan metode ekstraksi fitur pada pengklasifikasi Improved K-nearest Neighbor dan penentuan sudut.

Dimana, Nilai rata-rata accuracy, precision, dan recall tertinggi didapatkan pada penggunaan metode ekstraksi GLRLM dengan besar sudut $135^{\circ}$, yaitu accuracy $=90,4 \%$, precision $=75,7 \%$, dan recall $=76 \%$. Untuk nilai rata-rata accuracy, precision, dan recall terendah didapatkan pada penggunaan metode ekstraksi GLCM dengan besar sudut $90^{\circ}$, yaitu accuracy $=80,8 \%$, precision $=50,4 \%$, dan recall $=52 \%$. Pada identifikasi jenis sampah berdasarkan citra sampah yang dilakukan pada penelitian ini, penggabungan nilai ciri dari metode ekstraksi GLCM dan nilai ciri dari metode ekstraksi GLRLM belum sepenuhnya mampu meningkatkan ketepatan hasil identifikasi dengan nilai rata-rata accuracy, precision, dan recall tertinggi didapatkan pada besar sudut $0^{\circ}$, yaitu accuracy $=88 \%$, precision $=69,6 \%$, dan recall $=70 \%$.

\section{KESIMPULAN}

Beberapa kesimpulan yang dihasilkan dalam penelitian ini untuk identifikasi jenis sampah berdasarkan tekstur dengan Metode Gray Level Co-Occurrence Matrix (GLCM) dan Gray Level Run Length Matrix (GLRLM) menggunakan metode klasifikasi Improved K-Nearest Neighbor, yaitu:

1. Menerapkan metode GLRLM dapat meningkatkan kinerja pengklasifikasi Improved K-nearest Neighbor dalam mengidentifikasi jenis sampah dengan besar sudut $135^{\circ}$.

2. Penggabungan metode GLRLM dan metode GLCM tidak memberikan dampak positif pada pengklasifikasian Improved K-Nearest Neighbor kecuali dengan citra uji yang berbahan kertas. 


\section{REFERENCES}

[1] M. Handayani and A. Purwanto, "Pemanfaatan Barang Bekas Untuk Menumbuhkan Sikap Peduli Lingkungan Di SD Budi Mulia Dua Bintaro," Metodik Didaktik, 2019.

[2] T. S. a. D. R. I. M. S. F. S. Ni'mah, "Identifikasi Tumbuhan Obat Herbal Berdasarkan Citra Daun Menggunakan Algoritma Gray Level Co-occurence Matrix dan K-Nearest Neighbor," Jurnal Teknologi dan Sistem Komputer, vol. 6, no. 2, pp. 51-56, 2018.

[3] R. U. H. a. D. A. E. P. Purwandari, "Identifikasi Jenis Bambu Berdasarkan Tekstur Daun dengan Metode Gray Level Co-Occurrence Matrix dan Gray Level Run Length Matrix," Jurnal Teknologi dan Sistem Komputer, vol. 6, no. 4, pp. 146-151, 2018.

[4] D. H. Amelia, "Identifikasi Biometrik Pola Enamel Gigi Menggunakan Metode Grey Level Run Length Matrix (GLRLM) Dan Klasifikasi K-Nearest Neighbor (K-NN) Sebagai Aplikasi Forensik Kedokteran Gigi Berbasis Matlab," Universitas Telkom, Telekomunikasi, Bandung, 2018.

[5] S. S. Y. \&. W. R. Adha, "Klasifikasi Jenis Citra Makanan Tunggal Berdasarkan Fitur Local Binary Patterns dan Hue Saturation Value Menggunakan Improved K-Nearest Neighbor," Jurnal Pengembangan Teknologi Informasi dan Ilmu Komputer, vol. 3, no. 3, pp. 2416-2424, 2019.

[6] S. Wagle, J. A. Mangai and V. S. Kumar, "An Improved Medical Image Classification Model using Data Mining Techniques," 7th IEEE GCC Conference and Exhibition (GCC), Vols. 114-118, 2013.

[7] H. Z. \&. Zhang, "“A Normal Distributions-Based Over-Sampling Approach to Imbalanced Data Classification. Advanced Data Mining and Applications," in International Conference, Beijing, 2011.

[8] D. Untari, "DATA MINING UNTUK MENGANALISA PREDIKSI MAHASISWA BERPOTENSI NONAKTIF MENGGUNAKAN METODE DECISION TREE C4.5," Universitas Dian Nuswantoro, Semarang, 2014.

[9] M. Bramer, Principles of Data Mining, London: Springer, 2007.

[10] E. Prasetyo, Mengolah Data Menjadi Informasi Menggunakan Matlab, A. Sahala, Ed., Yogyakarta: ANDI, 2014.

[11] R. A. Surya, A. Fadlil and A. Yudhana, "Ekstraksi Ciri Metode Gray Level CoOccurrence Matrix (GLCM) dan Filter," Jurnal Informatika: Jurnal Pengembangan IT, vol. 2, no. 2, 2017.

[12] R. Munir, "Image Enhancement," in Pengolahan Citra Digital, Bandung, 2004.

[13] E. Alvansga, "Pengenalan Tekstur Menggunakan Metode GLCM Serta Modul Nirkabel," 2019.

[14] M. S. Munir, "Klasifikasi Kekurangan Unsur Hara N,P,K Tanaman Kedelai Berdasarkan Fitur Daun Menggunakan Jaringan Syaraf Tiruan," Institut Teknologi Sepuluh Nopember, Surabaya, 2016.

[15] M. Galloway, "Texture Analysis Using Gray Level Run Length Matriks," in Computer Science Center, University of Maryland, 1975, pp. 415-420.

[16] L. Jefry, "Implementasi Metode Run Length Dan Simple Naïve Bayes Untuk Klasifikasi Penyakit Leukemia Berdasarkan Citra Darah," Jurnal Ilmiah Komputer dan Informatika (KOMPUTA), 2016.

[17] F. D. Faustina, "Identifikasi Pola Kerapuhan Tulang Berdasarkan Fitur Tekstur Citra Dental Panaromic Radiograph (DPR) Menggunakan Gray Level Run Length Matrix (GLRLM) dan Support Vector Machine (SVM)," 2019.

[18] Y. G. K, I. Santoso and R. R. Isnanto, "Klasifikasi Citra dengan Matriks Ko-Okurensi Aras Keabuan (Gray level co-occurrence matrix-GLCM) pada Lima Kelas Biji-Bijian," Universitas Diponegoro, Semarang, 2011.

[19] R. Munir, Pengantar Pengolahan Citra, Pengolahan Citra Digital, 2013, pp. 1-10.

[20] S. \&. W.R.Adha, ""Klasifikasi Jenis Citra Makanan Tunggal Berdasarkan Fitur Local Binary Patterns dan Hue Saturation Value Menggunakan Improved K-Nearest Neighbor"," Jurnal Pengembangan Teknologi Informasi dan Ilmu Komputer, vol. 3, pp. 2416-2424, 2019. 